\title{
ARTICLE Role and regulation of Cdc25A phosphatase in neuron death induced by NGF deprivation or $\beta$-amyloid
}

\author{
Nandini Chatterjee ${ }^{1,3}$, Priyankar Sanphui ${ }^{1,3}$, Stav Kemeny ${ }^{2}$, Lloyd A Greene ${ }^{2}$ and Subhas C Biswas ${ }^{1}$
}

Neuron death during development and in Alzheimer's disease (AD) is associated with aberrant regulation/induction of cell cycle proteins. However, the proximal events in this process are unknown. Cell cycle initiation requires dephosphorylation of cyclindependent kinases by cell division cycle 25A (Cdc25A). Here, we show that Cdc25A is essential for neuronal death in response to NGF deprivation or $\beta$-amyloid (A $\beta$ ) treatment and describe the mechanisms by which it is regulated in these paradigms. Cdc25A mRNA, protein and Cdc25A phosphatase activity were induced by NGF deprivation and A $\beta$ treatment. Enhanced Cdc $25 A$ expression was also observed in rat brains infused with $A \beta$ and in $A \beta$-overexpressing $A \beta P P$ swe-PS1dE9 mice. In cultured neurons Cdc $25 A$ inhibition by chemical inhibitors or shRNA prevented cell death and neurite degeneration caused by NGF deprivation or $A \beta$. Additionally, Cdc25A inhibition diminished distal signaling events including Cdk-dependent elevation of phospho-pRb and subsequent caspase- 3 activation. Mechanism studies revealed that Cdc25A induction by NGF deprivation and A $\beta$ is mediated by activation of Forkhead transcription factors that in turn suppress miR-21, a negative regulator of Cdc25A. Our studies thus identify Cdc25A as a required upstream element of the apoptotic cell cycle pathway that is required for neuron death in response to trophic factor deprivation and to $A \beta$ exposure and therefore as a potential target to suppress pathologic neuron death.

Cell Death Discovery (2016) 2, 16083; doi:10.1038/cddiscovery.2016.83; published online 12 December 2016

\section{INTRODUCTION}

Neuron death is a physiological process during development and contributes to the pathophysiology of various neurodegenerative diseases including Alzheimer's disease (AD). During development about half of neurons die due to lack of target-derived trophic support such as caused by limiting supplies of NGF. ${ }^{1}$ In $A D$, a major cause of neuron degeneration is thought to be due to oligomerization and accumulation of $\beta$-amyloid $(A \beta)$ protein. ${ }^{2-6}$ Alterations of NGF metabolism and signaling are also implicated in $A D .^{7,8}$ However, the mechanisms of neuron death in the absence of NGF or in response to oligomeric $A \beta$ remain incompletely understood. Aside from increasing understanding of the nervous system, a comprehensive description of neuronal death mechanisms could provide insight to better strategies for treatment of diseases characterized by neuron degeneration.

Accumulating evidence strongly suggests that in response to a wide variety of proapoptotic conditions, including trophic factor deprivation, exposure to $A \beta$, DNA damage and oxidative stress, postmitotic neurons emerge from the $G_{0}$ state of the cell cycle with aberrant and potentially fatal expression/activation of cell cycle proteins. ${ }^{9-16}$ Studies with NGF deprivation, A $\beta$ treatment or DNA-damaging agents have yielded a consistent set of events related to the cell cycle that culminate in apoptotic neuron death. Among initial responses is activation of G1/S cyclin-dependent kinases (Cdks) such as Cdk4. This in turn phosphorylates retinoblastoma ( $\mathrm{pRb}$ ) family proteins and leads to dissociation of repressor complexes comprising E2F and pRb proteins such as p130, so that E2F-binding genes are de-repressed. Among genes that are de-repressed by loss of E2F-Rb family complexes are the B- and C-myb transcription factors and these in turn transactivate
Bim, a proapoptotic protein that promotes caspase activation and subsequent neuron death. ${ }^{12,13,17,18}$

Exit from $G_{0} / G_{1}$ and initiation of the cell cycle requires dephosphorylation of inhibitory phosphates on adjacent threonine and tyrosine residues of Cdks such as Cdk4. This is accomplished by the dual specificity phosphatase, cell division cycle $25 \mathrm{~A}(\mathrm{Cdc} 25 \mathrm{~A})$ a member of a phosphatase family comprising Cdc25 A, B and C. ${ }^{19}$

The current work addresses several key unanswered questions regarding the potential role of Cdc25A in neuron death. First, does Cdc25A in particular play a required role in neuron death and activation of the apoptotic cell cycle pathway caused by neurotrophic deprivation? Is this also the case for $A \beta$ treatment? Is Cdc25A upstream of other known events in the pathway? Do neurotrophic deprivation and $A \beta$ treatment lead to elevated Cdc25A levels? If so, what is the signaling mechanism that links induction of Cdc25A to these apoptotic stimuli? Because Cdc25A is an inhibitable enzyme, addressing these issues identifies Cdc25A as a potential target to block pathologic neuron degeneration and death.

\section{RESULTS}

Early induction and activation of Cdc25A following NGF withdrawal

To examine whether Cdc25A plays a role in neuron death, we initially employed neuronally differentiated PC12 cells. PC12 cells neuronally differentiate in the presence of NGF and require NGF for survival in the absence of serum. ${ }^{20}$ Like sympathetic neurons, upon NGF deprivation these cells undergo apoptotic death

\footnotetext{
${ }^{1}$ Cell Biology and Physiology Division, CSIR-Indian Institute of Chemical Biology, 4 Raja S. C. Mullick Road, Kolkata 700032 , India and ${ }^{2}$ Department of Pathology and Cell Biology, Columbia University Medical Center, New York, NY 10032, USA.

Correspondence: SC Biswas (biswassc@gmail.com or subhasbiswas@iicb.res.in)

${ }^{3}$ These authors contributed equally to this work.

Received 16 September 2016; accepted 23 September 2016; Edited by A Rufini
} 
starting at about $16 \mathrm{~h}$ with about half dying by $24 \mathrm{~h} .{ }^{21}$ Assessment of Cdc25A transcripts levels in neuronal PC12 cells following NGF withdrawal by both semiquantitative (Figure 1a) and quantitative RT-PCR (Figure $1 \mathrm{~b}$ ) revealed significantly increased Cdc25A mRNA levels within $2 \mathrm{~h}$ of NGF withdrawal. We confirmed these results in primary cultures of rat neonatal sympathetic neurons cultured for 5 days and subjected to NGF deprivation for $2 \mathrm{~h}$. In this case also, semiquantitative (Figure 1c) and quantitative PCR (Figure 1d) showed significantly increase in Cdc25A transcripts following $2 \mathrm{~h}$ of NGF withdrawal.

We next determined whether the increase in Cdc25A transcripts was reflected in Cdc25A protein levels. Western blotting showed that Cdc25A protein levels significantly increased in a timedependent manner by 2-3-fold in neuronal PC12 cells following NGF withdrawal (Figures $1 \mathrm{e}$ and $\mathrm{f}$ ) and in primary sympathetic neurons following $8 \mathrm{~h}$ of NGF withdrawal (Figures $1 \mathrm{~g}$ and $\mathrm{h}$ ).

We also assessed whether Cdc25A phosphatase activity is similarly increased in response to $8 \mathrm{~h}$ NGF deprivation and observed a significant doubling of activity compared with that of controls (Figure 1i). Collectively, these experiments indicate that NGF deprivation causes a relatively rapid induction of Cdc25A mRNA, protein and activity well before death is evident.

Cdc25A activity and expression are required for death caused by NGF deprivation

Next we investigated whether Cdc25A activity and expression are required for NGF deprivation-induced cell death. To assess the activity requirement, we treated neuronal PC12 cells with anti-NGF in the presence and absence of the Cdc25 inhibitors NSC663284 and NSC95397 and assayed cell viability. Both drugs conferred protection and, importantly, protected neurites from degeneration (Figures $2 \mathrm{a}$ and b). A similar experiment with rat sympathetic neuron cultures revealed that NSC95397 showed significant protection from NGF deprivation (Figures $2 c$ and d) as well as neurite retention (Figure $2 \mathrm{c}$ ).

Because inhibitors may have nonspecific effects and are not selective (that is also block Cdc25B and C), we used shRNA to specifically suppress Cdc25A expression. Efficacy of the construct was verified in that it substantially diminished expression of endogenous and exogenously expressed Cdc25A (Figures 2e and $f$ and data not shown). Compared with a control construct (shRand, a scrambled shRNA), sh(dc25A significantly protected neuronal PC12 cells and sympathetic neurons from death induced by NGF deprivation (Figures 2g-i). Moreover, a majority of shCdc25Atransfected neurons maintained their overall neuronal morphology after NGF deprivation (Figure 2h). Taken together these experiments indicate that interfering with Cdc25A activity or expression not only protects neurons from death but also preserves their morphology following NGF deprivation. Thus, $\mathrm{Cdc} 25 \mathrm{~A}$ is a required element in the death mechanism.

\section{$\operatorname{Cdc} 25 \mathrm{~A}$ is induced in cortical neurons by $A \beta$}

An extensive literature links NGF, $A D$ and $A \beta^{22}$ and the molecular mechanisms of neuronal cell death evoked by either NGF deprivation or $A \beta$ treatment have many commonalities including activation of cell cycle molecules. ${ }^{13}$ We therefore examined whether $\operatorname{Cdc} 25 \mathrm{~A}$ is affected and plays a role in $\mathrm{A} \beta$-induced neurodegeneration. Cultured cortical neurons and neuronal PC12 cells were exposed to $1.5 \mu \mathrm{M}$ oligomeric $\mathrm{A} \beta$ and $5 \mu \mathrm{M}$ oligomeric $A \beta$, respectively (Figures $3 a$ and $b$ ), levels that cause cell death within $24 \mathrm{~h}^{23}$ Semiquantitative PCR showed a doubling in Cdc25A transcripts within $2 \mathrm{~h}$ of treatment in cortical cultures (Figure $3 \mathrm{a}$ ) and a similar change within an hour in PC12 cell cultures (Figure $3 \mathrm{~b}$ ). The increase in transcripts in cortical neurons was reflected by a significant two- to three-fold elevation of Cdc25A protein expression by $8-16 \mathrm{~h}$ of $A \beta$ exposure (Figures $3 c$ and $d$ ). Immunocytochemical analysis also confirmed increased Cdc25A protein levels in cortical neurons following $A \beta$ treatment (Figure 3e). Our results thus indicate that Cdc25A is elevated in neurons by $A \beta$ and by NGF deprivation and that this occurs well before onset of death.

\section{Cdc25A is elevated in vivo in AD models}

To complement our culture studies, we next asked whether Cdc25A is induced in in vivo models of AD. To do so, we infused oligomeric $A \beta$ or the reverse peptide $A \beta_{(42-1)}$ into right hemispheres of rat brains. We and others have shown that this causes $A \beta$ accumulation and neuron death near the infusion site. ${ }^{23}$ The animals were killed 21 days post infusion. Immunohistochemical analysis of the brains revealed a significant upregulation of Cdc25A protein levels near the sites of infusion with $A \beta$ compared with infusion with $A \beta_{(42-1)}$ (Figure $3 f$ ).

As a second model, we examined brain sections of a $\beta P P$ swePS1sde9 (Swedish mutations in APP and PS1) transgenic mice for Cdc25A expression. Congo red staining confirmed significant amounts of $A \beta$ plaques in the transgenic mouse brains (data not shown), with no such plaques in control littermates. Immunohistochemical analysis showed a considerable increase in Cdc25A expression in the transgenic mice compared with control littermates (Figure $3 \mathrm{~g}$ ). Collectively, these findings indicate that Cdc25A is upregulated in both in vitro and in vivo models of $A D$.

$\operatorname{Cdc} 25 \mathrm{~A}$ is required for $A \beta$-induced neuron death and degeneration

We next examined whether $\mathrm{Cdc} 25 \mathrm{~A}$ is required in $\mathrm{A} \beta$-induced neuronal death as it is for NGF withdrawal. Cortical neuron cultures were transfected with shCdc25A or shRand and exposed to $A \beta$ and living transfected (Zsgreen+) cells were counted at 24 and $48 \mathrm{~h}$. Cdc25A downregulation provided significant protection to neurons from death evoked by $A \beta$ (Figure $4 a$ and b). Moreover, Cdc25A knocked down neurons retained normal neuronal morphology after $A \beta$ exposure, which contrasted with degeneration of neurites in $A \beta$-treated shRand-transfected neurons (Figure 4a).

Cdc25A lies upstream of and is required for $\mathrm{Rb}$ phosphorylation and caspase- 3 cleavage after NGF deprivation or $A \beta$ treatment

A molecular pathway has been described that includes cell cyclerelated molecules and that plays a required role in neuron death induced by NGF deprivation or $A \beta$ treatment. ${ }^{13}$ As dissected thus far, the pathway starts with activation of $\mathrm{Cdk} 4$, which in turn phosphorylates proteins of the $\mathrm{Rb}$ family, thereby triggering a series of events that lead to caspase- 3 activation and subsequent neuron death. We therefore asked whether Cdc25A is upstream of Cdk4 in this scheme. If Cdc25A acts upstream of Cdk4, then suppression/inhibition of Cdc25A should in turn block Cdk4dependent $\mathrm{Rb}$ phosphorylation and subsequent activation of caspase- 3 by NGF deprivation or A $\beta$ treatment. Indeed, when we assessed NGF-deprived PC12 cells by immunostaining, we found that shCdc25A treatment greatly reduced the proportion with high levels of phospho-Rb (Figure $5 a$ and b). Similarly, $A \beta$ treatment elevated levels of phosphorylated $\mathrm{Rb}$ in neuronal PC12 cells and this was blocked by Cdc25A knockdown (Figure 5c and d). We additionally analyzed phosphorylated $\mathrm{Rb}$ by western blotting after Cdc25 inhibition with NSC95397 in the presence and absence of NGF. Blocking Cdc25 activity substantially suppressed phosphorylation induced by NGF deprivation (Figure 5e). Finally, we found that Cdc25 inhibition by NSC95397 significantly blocked NGF-deprivation-induced caspase-3 cleavage (Figure $5 \mathrm{f}$ and $\mathrm{g}$ ). Thus these experiments indicate that Cdc25A is upstream of and required for activation of cell-cycle-related pathways involved in neuronal death following NGF deprivation and $A \beta$ exposure. 


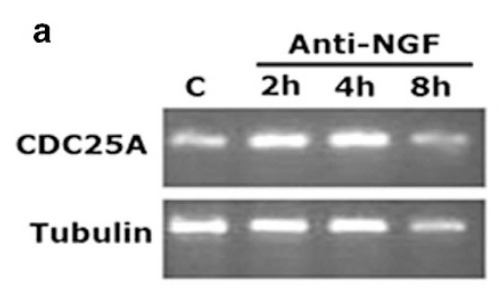

b

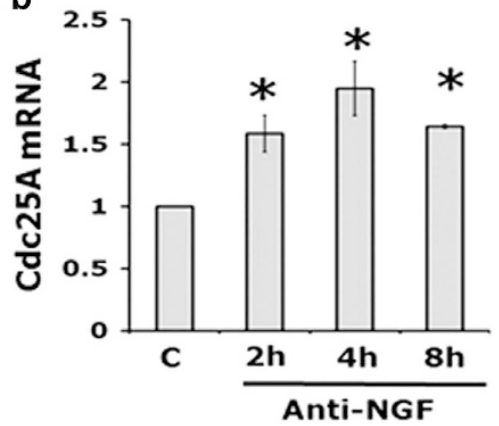

e
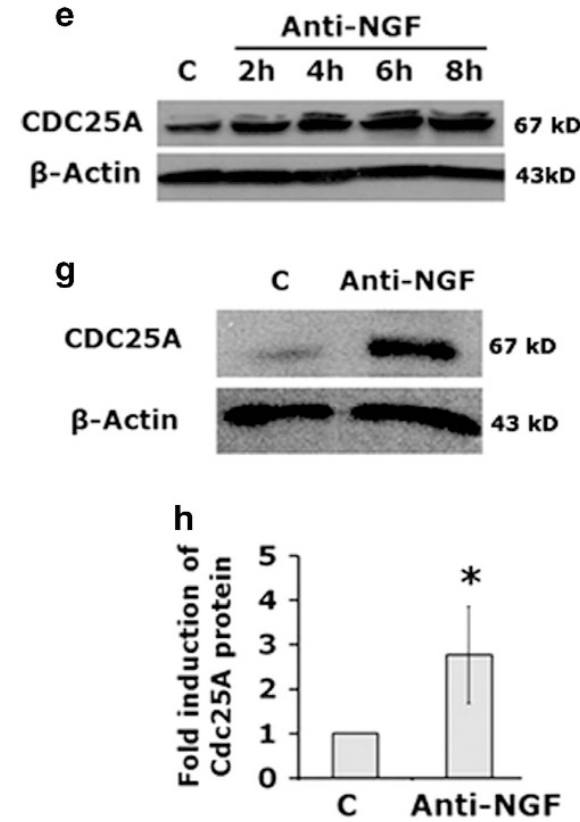

c

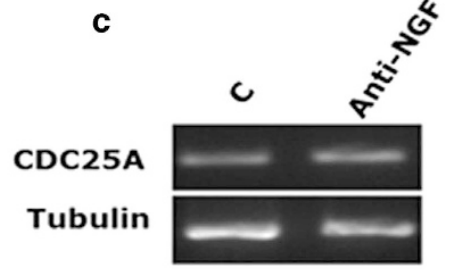

d

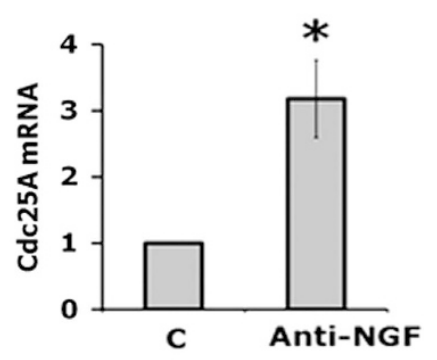

Figure 1. Cdc25A RNA levels, protein levels and its activity are elevated in neuronal cells following NGF deprivation. (a and b) Neuronally differentiated PC12 cells were subjected to NGF deprivation for indicated times and total RNA was isolated from harvested cells. (a) The RNA was analyzed by semiquantitative PCR for Cdc25A transcript levels. $a$-Tubulin was used as a loading control. Representative figure of three independent experiments with similar results is shown. (b) Quantitative real-time PCR of Cdc25A transcripts levels. GAPDH was used as a loading control. Data are represented as mean \pm S.E.M. of four independent experiments. Asterisks denote statistically significant differences from control, ${ }^{*} P<0.05$. (c and d) Primary rat sympathetic neurons (5 DIV) were subjected to NGF deprivation for $2 \mathrm{~h}$. Total RNA was isolated from harvested cells. (c) The RNA was analyzed by semiquantitative PCR for Cdc25A transcript levels. $a$-Tubulin was used as loading control. A representative image is shown of one of two independent experiments with similar results. (d) The RNA was analyzed by quantitative RT-PCR for Cdc25A transcript levels as described in (b). Data are represented as mean \pm S.E.M. of three independent experiments, ${ }^{*} P<0.05$. (e) Neuronally differentiated PC12 cells were treated with anti-NGF for indicated times. Total protein was subjected to western blotting analysis using specific Cdc25A antibody. $\beta$-Actin was used as a loading control. A representative immunoblot of four independent experiments with similar results is shown. (f) Graphical representation of the Cdc25A protein levels as quantified by densitometry of western blots in neuronal PC12 cells subjected to NGF deprivation for $8 \mathrm{~h}$. Data are represented as mean \pm S.E.M. of four independent experiments, ${ }^{*} P<0.05$. (g) Primary rat sympathetic neurons (5 DIV) were subjected to NGF deprivation for $8 \mathrm{~h}$. Total cell lysates were subjected to western blotting analysis for Cdc25A protein levels. $\beta$-Actin was used as a loading control. A representative immunoblot of three independent experiments with similar results is shown. (h) Graphical representation of the Cdc25A protein levels as quantified by densitometry of western blots in sympathetic neurons subjected to NGF deprivation for $8 \mathrm{~h}$. Data are represented as mean \pm S.E.M. of three independent experiments, ${ }^{*} P<0.05$. (i) Differentiated PC12 cells were subjected to NGF withdrawal for $8 \mathrm{~h}$. Cdc25A was immunoprecipated and subjected to phosphatase activity assay as described under 'Materials and Methods'. Data represent mean \pm S.E.M. of three independent experiments, $* P<0.05$. 
FoxO transcription factors are required for induction of $\mathrm{Cdc} 25 \mathrm{~A}$ following $A \beta$ treatment

Next we explored the molecular mechanism by which Cdc25A expression is regulated. Because $\mathrm{Cdc} 25 \mathrm{~A}$ is regulated by multiple signaling pathways, including the JNK, ERK and AKT pathways in proliferating cells, ${ }^{19}$ we first assessed specific pathway inhibitors for their effects on Cdc25A expression in neuronal PC12 cells. Although JNK and ERK pathway inhibitors had no effects on Cdc25A levels, inhibition of the AKT pathway for $16 \mathrm{~h}$ led to elevated $\operatorname{Cdc} 25 \mathrm{~A}$ expression comparable to that achieved by exposure to $A \beta$ or NGF deprivation (Figure 6a). FoxO family transcription factors are direct targets of the PI3K/AKT pathway a

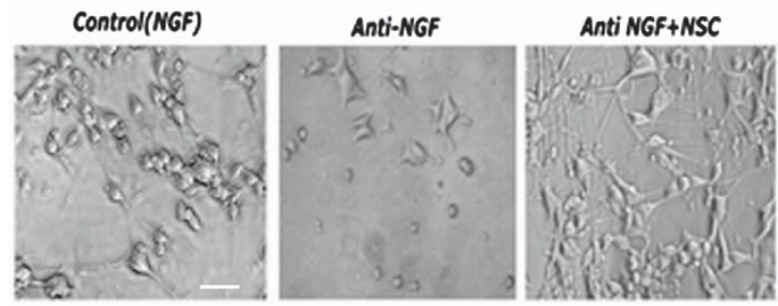

C

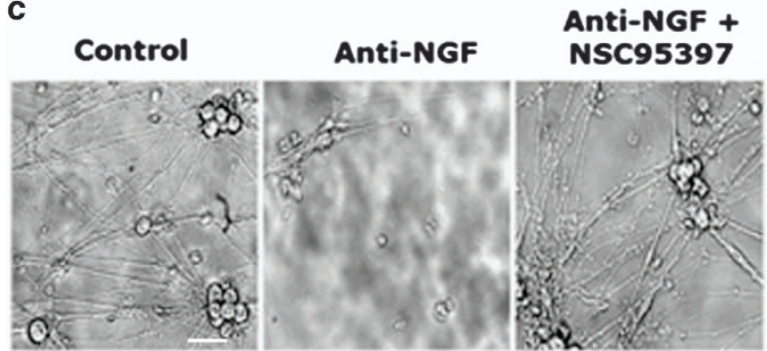

b

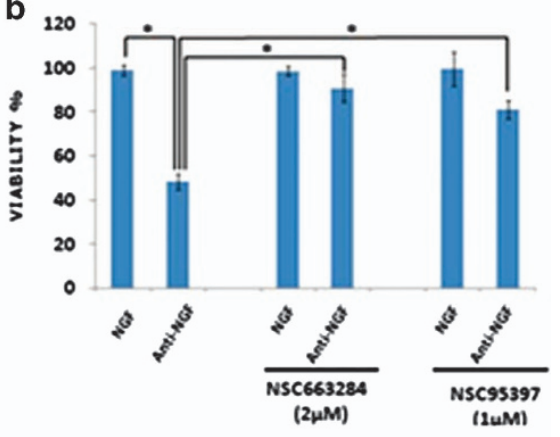

d
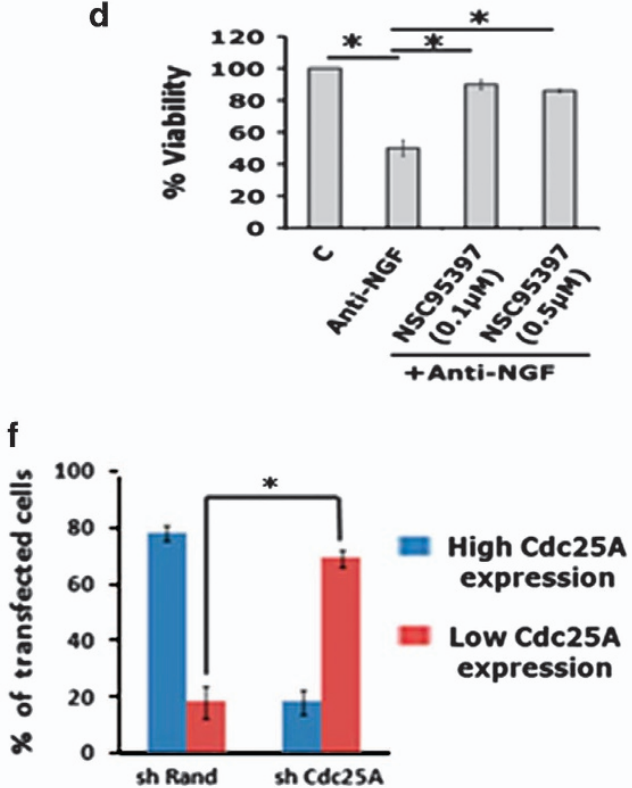

h
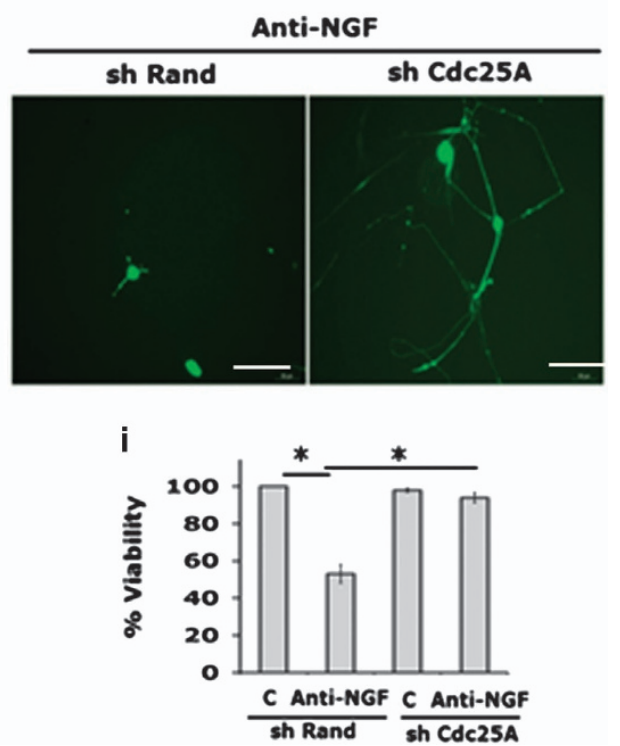
that are inactivated by Akt-mediated phosphorylation and that are thus activated when PI3K/AKT signaling is blocked. ${ }^{24,25}$ We previously reported that $\mathrm{FoxO} 3 \mathrm{a}$ activation plays a necessary role in $\mathrm{A} \beta$-induced neurodegeneration ${ }^{23}$ and FoxO activation is required for neuron death caused by NGF deprivation and consequent shut-down of Akt activity. ${ }^{26,27}$ We therefore hypothesized that $\mathrm{Cdc} 25 \mathrm{~A}$ upregulation in our death models is mediated by FoxOs. To test this in the $A \beta$ model, we knocked down FoxOs in neuronally differentiated $\mathrm{PC} 12$ cells with a previously reported shRNA that targets all FoxO isoforms ${ }^{18}$ and determined levels of both $\mathrm{Cdc} 25 \mathrm{~A}$ transcripts and protein. $\mathrm{A} \beta$ upregulated $\mathrm{Cdc} 25 \mathrm{~A}$ in control (shRand transfected) cells as expected, and this was blocked/diminished in cells in which FoxOs were downregulated by shRNA (Figures $6 \mathrm{~b}$ and $\mathrm{c}$ ). Collectively, these results indicate that FoxO transcription factors are required for Cdc25A upregulation by $A \beta$.

FoxOs elevate $\mathrm{Cdc} 25 \mathrm{~A}$ expression by suppressing miR-21 levels following $A \beta$ treatment

We next probed the mechanism by which FoxOs regulate $\mathrm{Cdc} 25 \mathrm{~A}$ in response to $A \beta$ treatment. Because FoxOs are transcription factors, we initially considered that they may regulate $\mathrm{Cdc} 25 \mathrm{~A}$ by binding directly to its promoter. However, examination of the promoter sequence did not reveal potential FoxO binding sites. It has been reported that FoxO3a transcriptionally represses miR-21 in cancer cells following doxorubicin treatment ${ }^{28}$ and that miR-21 negatively regulates Cdc25A. ${ }^{29}$ We therefore assessed whether FoxOs regulate $C d c 25 A$ via miR-21 in the context of $A \beta$ treatment. We initially measured miR-21 levels in cortical and hippocampal neurons following $A \beta$ treatment and found a significant reduction at $2(30-60 \%)$ and $8 \mathrm{~h}(60-90 \%)$ after $A \beta$ exposure (Figures $7 \mathrm{a}$ and $b$ ). To determine whether this response is mediated by FoxOs, we knocked down FoxOs in neuronal PC12 cells, treated them with $A \beta$ and assessed miR-21 levels by RT-PCR. This also revealed a substantial reduction in miR-21 following $A \beta$ treatment and this effect was completely abolished in FoxO knockdown cells (Figure 7c). These findings thus indicate that $A \beta$ negatively regulates miR-21 in neuronal cells and that this action is mediated by FoxO transcription factors.

Next, we evaluated whether the $A \beta$-promoted decrease in miR-21 levels is responsible for elevating Cdc25A expression. For these experiments, we overexpressed miR-21 activity in neuronally differentiated PC12 cells by transfecting them with an miR-21 mimic or with a control mimic in the presence or absence of $A \beta$. Our reasoning was that the overexpressed miR-21 mimic should over-ride the inhibitory actions of $A \beta$ on endogenous miR-21 levels and therefore suppress the elevation of $\mathrm{Cdc} 25 \mathrm{~A}$ caused by $A \beta$ exposure. RT-PCR verified that the cells transfected with the miR-21 mimic showed a large increase in miR-21 signal compared with cells transfected with the control mimic (Figure 7d). RT-PCR also showed upregulation of $\mathrm{Cdc} 25 \mathrm{~A}$ transcripts as anticipated following $A \beta$ exposure in the presence of the control mimic. Significantly, this upregulation was nearly completely blocked in miR-21 mimic-overexpressing cells (Figure 7e). Western blots also verified upregulation of $\operatorname{Cdc} 25 A$ protein following $A \beta$ treatment in the presence of the control mimic and that this effect was fully suppressed in cells transfected with the miR-21 mimic (Figures $7 f$ and $g$ ). Taken together our findings thus support a neuronal pathway in which $A \beta$ treatment activates FoxO transcription factors that in turn downregulate miR-21, leading to elevated $\mathrm{Cdc} 25 \mathrm{~A}$ expression.

\section{DISCUSSION}

One of the major signaling mechanisms that promote apoptotic neuron death is inappropriate activation of an apoptotic cell cycle pathway. A wealth of data indicates that activation of cell cycle molecules is linked to the core cell death machinery during development and in various neurological conditions. ${ }^{9,12-14,16,30,31}$ In response to apoptotic stimuli, G1/S cyclin-dependent kinases such as Cdk4 are activated and phosphorylate proteins of the $\mathrm{pRb}$ family. ${ }^{32}$ This in turn causes dissociation of repressor complexes comprising E2F family members and $\mathrm{pRb}$ proteins such as p130. ${ }^{12,13,33}$ Free E2F transcription factors activate myb transcription factors that participate in activation of proapoptotic proteins such as Bim that promote caspase activation and execution of neuron death. ${ }^{12,13,17,18,33}$ However, how Cdk4 is activated in the first place in postmitotic neurons in response to apoptotic stimuli has remained elusive.

One of the mechanisms by which Cdk4 is activated in proliferating cells is by dephosphorylation of its inhibitory phosphates on adjacent threonine and tyrosine residues by the dual specificity phosphatase $\operatorname{Cdc} 25 \mathrm{~A} .{ }^{19}$ In this study, we identified $\mathrm{Cdc} 25 \mathrm{~A}$ as a regulator of $\mathrm{Cdk} 4$ activity in neuron death in response to NGF deprivation and $A \beta$ treatment. We found that $\operatorname{Cdc} 25 A$ is induced in vitro by NGF deprivation and in vitro and in vivo by $A \beta$

Figure 2. Blocking Cdc25A by either pharmacological inhibitors or shRNA protects neuronal PC12 cells and primary sympathetic neurons from death induced by NGF deprivation. (a) Neuronal PC12 cells (5 DIV) were subjected to NGF deprivation in the presence and absence of NSC663284 or NSC95397 at the indicated concentrations for $20 \mathrm{~h}$. Upper panel: representative phase contrast micrographs show retention of neurites after NGF deprivation in the presence of NSC663284 $(2 \mu \mathrm{m})$. Scale bar: $50 \mu \mathrm{m}$. (b) Graphical representation of relative percentage of viable cells under the indicated conditions. Data are represented as mean \pm S.E.M. of three independent experiments performed in duplicates. The asterisk denotes statistically significant difference between indicated classes: ${ }^{*} P<0.01$. (c and d) Primary sympathetic neurons (5 DIV) were exposed to anti-NGF for overnight in the presence or absence of Cdc25 inhibitor NSC95397 at two different concentrations (0.1 and $0.5 \mu \mathrm{m})$. (c) Representative phase contrast micrographs of primary sympathetic cultures under the indicated conditions. Scale bar: $50 \mu \mathrm{m}$. (d) The corresponding quantitative data derived from direct counting of viable nuclei. Data are represented as mean \pm S.E.M. of three experiments. Asterisks denote statistically significant differences between the indicated groups. ${ }^{*} P<0.005$. (e and f) shRNA targeted to Cdc25A blocks expression of endogenous Cdc25A. (e) Undifferentiated PC12 cells that were transfected with the indicated constructs, maintained for $48 \mathrm{~h}$ and then immunostained with antibody against Cdc25A. Scale bar: $10 \mu \mathrm{m}$. (f) The percentage of transfected cells shows the proportion of transfected cells with high (more or equal than the neighboring non-transfected cells) or low (less than the neighboring non-transfected cells) Cdc25A immunoreactivity levels. Data are represented as mean \pm S.D. of two experiments: ${ }^{*} P<0.01$. (g) Differentiated PC12 cells (5 DIV) were transfected with shRand-zsgreen or shCdc25A-zsgreen and $48 \mathrm{~h}$ post transfection, the cells were subjected to NGF deprivation. The numbers of surviving-transfected (green) cells were counted at the indicated times under fluorescence microscopy. The percentages of viable cells are represented graphically. Data are represented as mean \pm S.D. of two independent experiments. The asterisk denotes statistically significant difference between indicated class: ${ }^{*} P<0.05$. (h and $\left.\mathbf{i}\right)$ Primary rat sympathetic neurons (5 DIV) were transfected with shRand-zsgreen or shCdc25A-zsgreen. Forty-eight hours post transfection, cells were subjected to overnight NGF deprivation. The numbers of surviving-transfected (green) cells were counted under fluorescence microscopy. (h) Representative images of transfected sympathetic neurons after NGF deprivation under each condition. Scale bar: $100 \mu \mathrm{m}$. (i) Graphical representation of percentage of viable cells. Data are represented as mean \pm S.E.M. of three experiments. Asterisks denote statistically significant difference between the indicated groups. ${ }^{*} P<0.05$. 


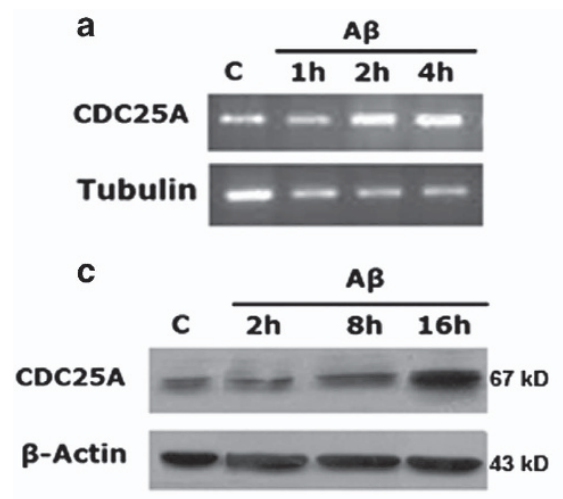

b
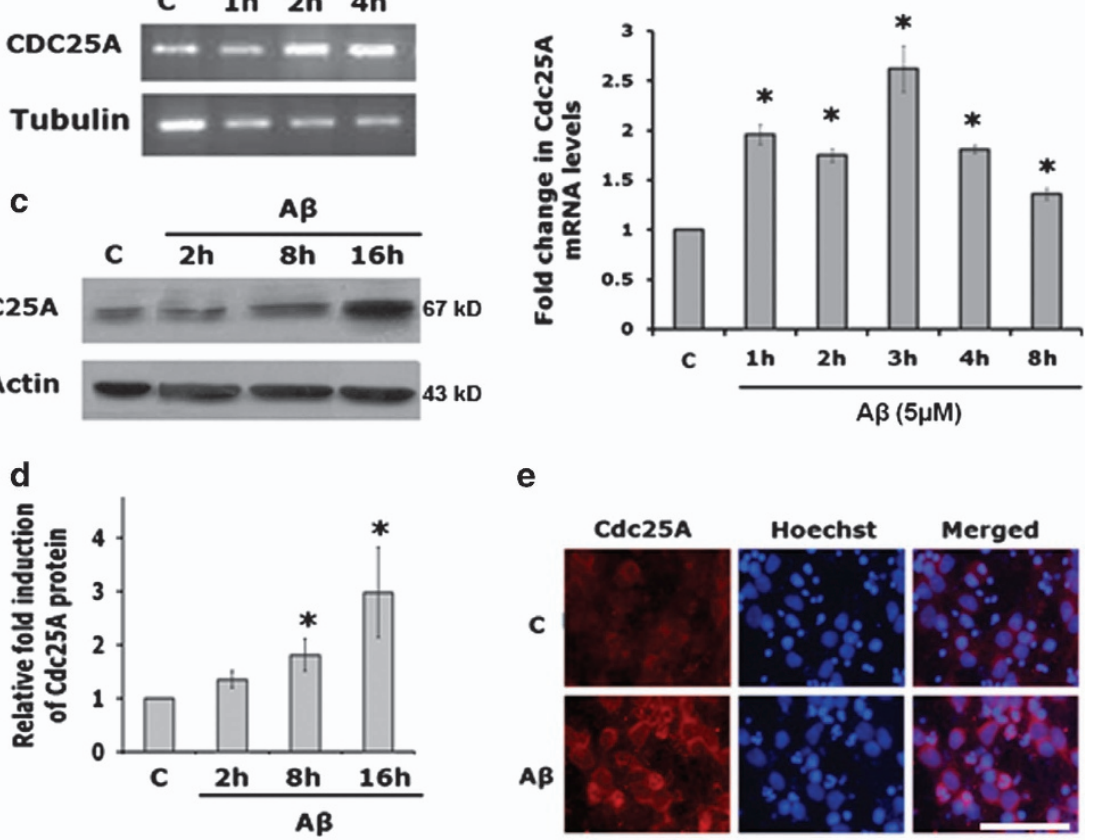

e
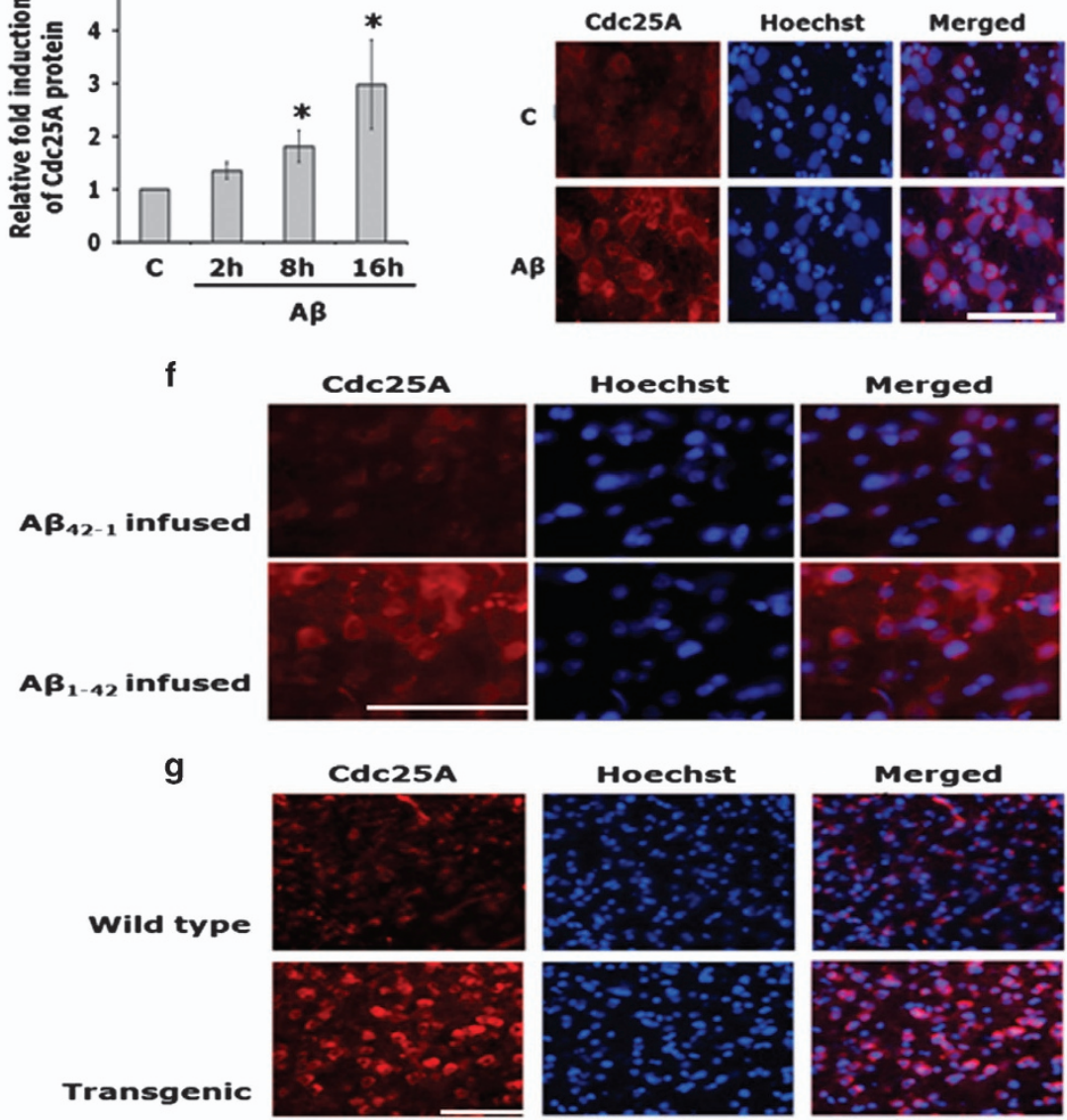

Figure 3. Cdc25A levels are elevated in primary rat cortical neurons and in vivo in response to $A \beta$. (a) Primary rat cortical neurons were treated with $A \beta$ for indicated times. Total RNA was isolated and used for semiquantitative PCR with specific primers for Cdc25A and $a$-tubulin. PCR products were resolved in a $1.5 \%$ agarose gel and stained with ethidium bromide. A representative gel image shows the relative Cdc25A and tubulin mRNA levels. (b) Neuronally differentiated PC12 cells were treated with A $\beta$ for indicated times. Total RNA was isolated and used for quantitative PCR with specific primers for Cdc25A. GAPDH was used as a loading control. The image shows graphical representation of mRNA of $C d c 25 A$ following $A \beta$ treatment. (c) Primary rat cortical neurons were treated with $A \beta$ for indicated times. Total proteins were extracted from $A \beta$-treated cortical neurons and analyzed by western blotting analysis for Cdc25A protein levels. A representative immunoblot of three independent experiments with similar results is shown. (d) Graphical representation of Cdc25A protein levels as quantified by densitometry. Data are represented as mean \pm S.E.M. of three independent experiments. Asterisks denote statistically significant differences between the indicated groups. ${ }^{*} P<0.05$. (e) Primary rat cortical neurons were treated with $A \beta$ for $16 \mathrm{~h}$ and immunostained with Cdc25A antibody. Hoechst dye 33342 was used to stain the nuclei. Representative images from one of three independent experiments with similar results are shown. Scale bar: $100 \mu \mathrm{m}$. (f) Oligomeric $\mathrm{A} \beta_{(1-42)}$ was infused into rat brain as described under 'Materials and Methods'. The animals were maintained for 21 days before killing. Brain sections were immunostained for $\mathrm{Cdc} 25 \mathrm{~A}$. The reverse peptide $A \beta_{(42-1)}$ was infused into control animals. Nuclei were stained with Hoechst dye 3342. Representative images of two sections from two different animals for each group with similar results are shown. Scale bar: $100 \mu \mathrm{m}$. (g) Brain sections of wild type and transgenic (A $\beta$ PPswe-PS1dE9) mice were immunostained with anti-Cdc25A antibody and nuclei were stained with Hoechst dye 3342. Representative images of two sections from three different transgenic animals and two wild-type animals with similar results are shown. Scale bar: $100 \mu \mathrm{m}$. 
a

$\mathbf{A \beta}$
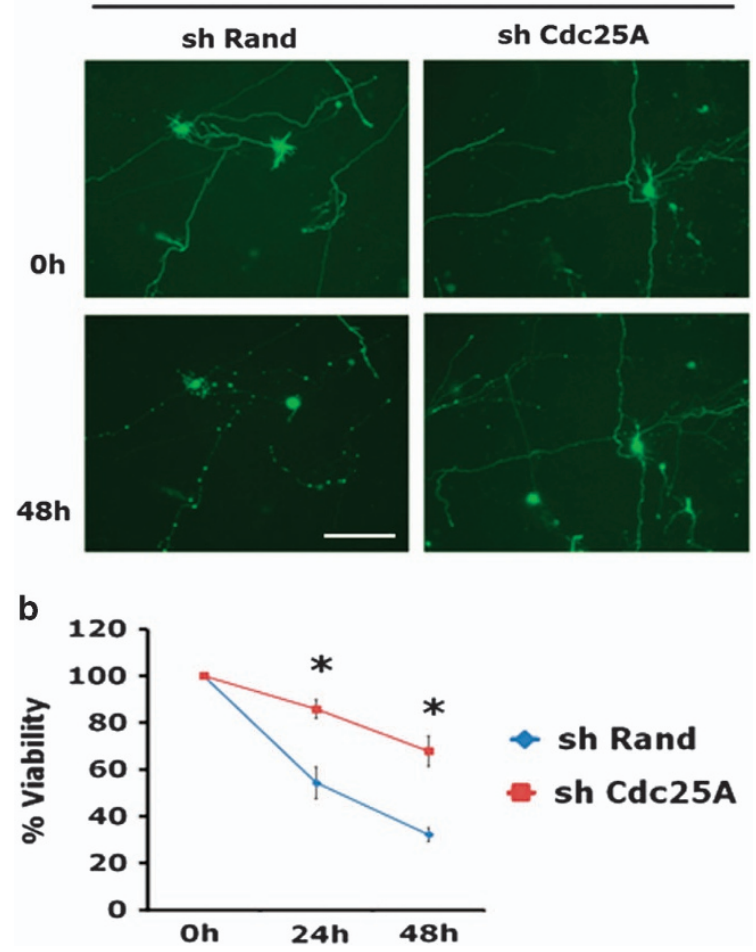

Figure 4. siRNA-mediated knockdown of Cdc25A protects primary cortical neurons against $A \beta$ toxicity. Primary rat cortical neurons (7 DIV) were transfected with shRand-zsgreen or shCdc25A-zsgreen. Forty-eight hours post transfection, neurons were treated with $A \beta$. Live green cells were counted at the indicated times after $A \beta$ treatment under fluorescence microscopy. (a) Representative images of cortical neurons transfected with shRand-zsgreen or shCdc25A-zsgreen and then exposed to $A \beta$ for $48 \mathrm{~h}$. (b) Graphical representation of the percentage of viable cells under each condition. Data are represented as mean \pm S.E.M. of three independent experiments performed in duplicates. The asterisks denote statistically significant difference from control (shRand): ${ }^{*} P<0.005$. Scale bar: $100 \mu \mathrm{m}$.

in various relevant models of AD. Moreover, its phosphatase activity is also enhanced to a similar degree in NGF-deprived neuronal cells. Importantly, inhibition of Cdc25A activity/expression by inhibitors or shRNA protected neurons from NGF deprivation and $A \beta$ treatment. These treatments also preserved neuronal morphology including neurites, indicating that $\mathrm{Cdc} 25 \mathrm{~A}$ and the apoptotic cell cycle pathway are involved in the neurite degeneration associated with trophic factor deprivation and $A \beta$ exposure. Altogether, our observations indicate that Cdc $25 \mathrm{~A}$ is rapidly elevated, activated and plays a required role in developmental and AD-relevant models of neuron death.

Our findings indicate that NGF deprivation and $A \beta$ lead to a rapid two- to three-fold induction of Cdc25A mRNA and protein. NGF withdrawal causes a similar increase in Cdc25A activity. These events occur at about the same time that apoptotic insults lead to Cdk4 activation and Rb phosphorylation in our systems $\mathrm{s}^{32}$ and well precede evident signs of neuron death. In line with a causal role for Cdc25A in these events, shRNA or an inhibitor targeting Cdc25 diminished phospho-pRb levels induced by NGF deprivation and $A \beta$ treatment. While our findings establish a role for $\mathrm{Cdc} 25 \mathrm{~A}$ in two death paradigms studied here, they do not indicate whether the increase in expression per se is essential for cell death. This possibility is supported by findings that Cdc25A overexpression is sufficient to cause neuronal cell death, ${ }^{34}$ that Cdc25A levels and activity increase in parallel in our study, and that death is averted when Cdc25A levels are reduced by shRNA. In non-neuronal cells,
Cdc25A levels are subject to regulation by protein stabilization. ${ }^{35}$ Our observations that $\mathrm{Cdc} 25 \mathrm{~A}$ transcripts and protein are induced to a similar degree suggest that this is not the case in our paradigms. A variety of post-translational modifications also have been shown to participate in Cdc25A regulation ${ }^{19,36}$ and it is plausible that these too contribute to elevation of neuronal Cdc25A activity in response to apoptotic insults.

Our findings establish for the first time that $\mathrm{Cdc} 25 \mathrm{~A}$ is a required upstream activator of the apoptotic cell cycle pathway in trophic factor-deprived neurons and that its levels under such conditions are elevated by a pathway involving FoxOs and miR-21. In the case of $A \beta$ there have been both relevant and conflicting findings that are addressed and significantly extended by our study. It has been reported that neurons in post-mortem brains from $A D$ patients have elevated Cdc25A immunostaining and that brain tissue from $A D$ patients has higher $C d c 25 A$ phosphatase activity compared with non-AD brains. ${ }^{37}$ Chang et al. ${ }^{38}$ found that $A \beta$ activates $\mathrm{Cdc} 25 \mathrm{~A}, \mathrm{~B}$ and $\mathrm{C}$ in cultured neurons and that a broad-spectrum $\mathrm{Cdc} 25$ inhibitor protects from $A \beta$-induced death. Elevated Cdc25 activity was associated with activation of, and phosphorylation by, cyclin-dependent kinase-5 (Cdk5) with no change in Cdc25 levels. In contrast, Kruman et al. ${ }^{39}$ described a three- to four-fold increase in $\mathrm{Cdc} 25 \mathrm{~A}$ protein in $\mathrm{A} \beta$-treated cortical neuron cultures. Our study thus favors a mechanism in which $A \beta$ elevates Cdc25A expression and activity and provides an explanation for how this occurs via FoxO-miR-21 signaling. Our causal data also clearly identify Cdc25A for the first time as a required player in $A \beta$ induced neuron death.

Zhang et $a .^{34}$ examined $\operatorname{Cdc} 25 \mathrm{~A}$ in the context of camptothecin-induced DNA damage to cultured neurons. Camptothecin activated $\mathrm{Cdc} 25 \mathrm{~A}$ within $2 \mathrm{~h}$ and inhibition or knockdown of Cdc25A was protective and blocked camptothecin-induced Cdk4 activation and $\mathrm{Rb}$ phosphorylation, thus linking it to the cell cycle pathway described above. However, in contrast to NGF deprivation and $A \beta$ treatment, $C d c 25 A$ activation by camptothecin did not change Cdc25A levels (and therefore not likely the FoxOmiR-21 pathway), but rather was correlated with loss of activity of the checkpoint 1 kinase (Chk1). Thus, it appears that although distal elements of the neuronal apoptotic cell cycle pathway are similar for different death inducers, multiple mechanisms exist to initiate the pathway via Cdc25A.

Our investigation of the mechanism of $\mathrm{Cdc} 25 \mathrm{~A}$ induction in neurons revealed a two- to three-fold elevation when Akt is inhibited. Neuronal Akt signaling is inhibited by oligomeric $A \beta^{23}$ and Akt activity is diminished in brains of AD patients and of APP trangenic mice. ${ }^{40}$ NGF deprivation also rapidly decreases Akt phosphorylation/activity. ${ }^{27}$ FoxO transcription factors are welldescribed Akt targets that are activated when Akt signaling is suppressed, ${ }^{41}$ and FoxO activation occurs and is required for neuronal death induced by trophic factor deprivation and $A \beta$ exposure. ${ }^{18,23,26,27}$ These considerations suggested that Cdc25A might be regulated by FoxOs. Indeed, FoxO downregulation by shRNA blocked upregulation of $\mathrm{Cdc} 25 \mathrm{~A}$ in $A \beta$-treated neurons. Because the $\operatorname{Cdc} 25 \mathrm{~A}$ gene has no consensus sequence for binding of FoxO transcription factors, we speculated that it might be regulated post-transcriptionally. It was reported that Cdc25A is suppressed by miR-21 in colon cancer cells ${ }^{29}$ and that FoxO3a induces apoptosis of lung cancer cells by negatively regulating miR-21 in response to doxorubicin. ${ }^{28}$ We found that a miR-21 mimic is sufficient to block Cdc25A mRNA and protein induction by $A \beta$ and that miR- 21 is downregulated in $A \beta$-treated neurons by a mechanism requiring FoxO transcription factors. These findings suggest a pathway in which NGF deprivation or $A \beta$ treatment leads successively to Akt inactivation, FoxO activation, suppression of miR-21 levels and consequent elevation of Cdc25A (Figure 8). Thus, our findings not only place elevated Cdc25A activity upstream of Cdk4 activation in the apoptotic neuronal death pathway, but also indicate a set of signaling events by which loss 
8

of trophic support or $A \beta$ exposure may regulate cellular $C d c 25 A$ levels and activity.

In conclusion, our study reveals that Cdc25A is both elevated and activated in neuronal cells by apoptotic stimuli relevant to normal development and to $A D$, and that it plays an essential role in neuronal degeneration and death in both instances. Targeting Cdc25A may therefore be a useful strategy for providing neuroprotection in $A D$ and other pathologies in which the neuronal apoptotic cell cycle pathway is activated. In this regard, a selective Cdc25A inhibitor has been effective in several nonneuronal experimental disease models and without reported toxicity. ${ }^{42-44}$

\section{MATERIALS AND METHODS}

\section{Materials}

Insulin, progesterone, putrescine, selenium, transferrin, anti-NGF, NGF, poly-D-lysine, NSC663284 and NSC95397 were purchased from Sigma
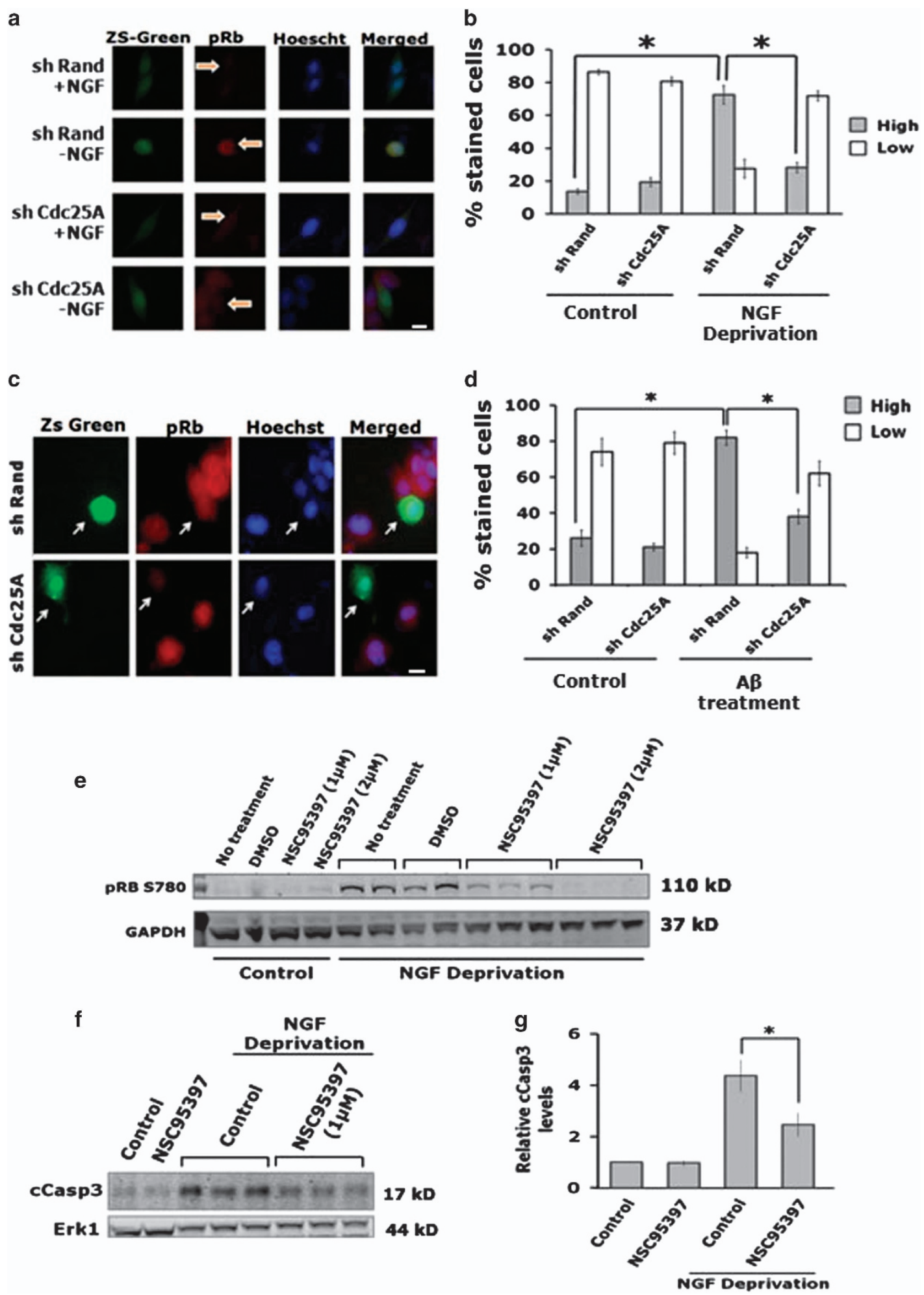
(St Louis, MO, USA). Cell culture media DMEM, DMEM-F12, RPMI-1640, Neurobasal, B27, antibiotics, Lipofectamine 2000, Alexa Fluor, cDNA synthesis kit, real-time PCR kit and serum were purchased from Invitrogen (Life technologies, Grand Island, NY, USA). Cell culture dishes, plates and flasks were purchased from BD Falcon, Corning (Corning, NY, USA). $A \beta_{(1-42)}$ and $A \beta_{(42-1)}$ were purchased from American Peptide (Sunnyvale, CA, USA). $E C L$ reagent and PVDF membrane were purchased from GE Healthcare (Buckinghamshire, UK). The PCR kits were purchased from Takara (Shiga, Japan), Fermentas (Waltham, MA, USA). Anti-Cdc25A, anti-Actin and HRP-conjugated secondary antibodies were purchased from Santa Cruz Biotechnology (Dallas, TX, USA). Anti-phospho-Rb antibody was purchased from Cell Signaling Technologies (Denver, MA, USA). AKT inhibitor II, JNK inhibitor II and U0126 were purchased from Calbiochem (Darmstadt, Germany). Primers were purchased from IDT DNA (Gurgaon,
Haryana, India). Brain tissues of A $\beta$ PPswe-PS1de9 mice and control littermates were a kind gift from Dr. Anant B. Patel (Council of Scientific and Industrial Research-Centre for Cellular and Molecular Biology (CSIR(CMB)), Hyderabad, India.

\section{Cell culture}

Rat pheochromocytoma cells (PC12) cells were cultured as described previously $^{20}$ and were grown in either DMEM or RPMI-1640 medium supplemented with $10 \%$ heat inactivated horse serum (HS) and $5 \%$ heat inactivated fetal bovine serum. Cells were neuronally differentiated by treatment with NGF $(50 \mathrm{ng} / \mathrm{ml})$ for 5-7 days in medium supplemented with $1 \%$ HS. Primary cortical neurons were cultured as described..$^{23,32,45}$ In brief, the neocortices of E-18 rat embryo were dissected out, dissociated and
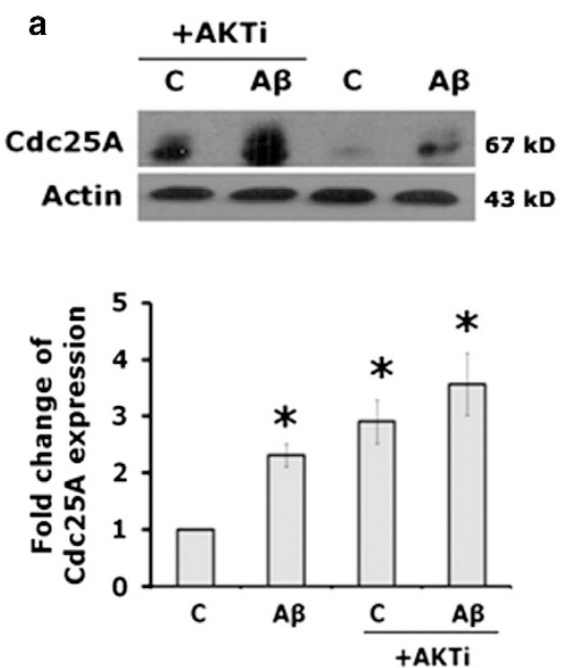

b

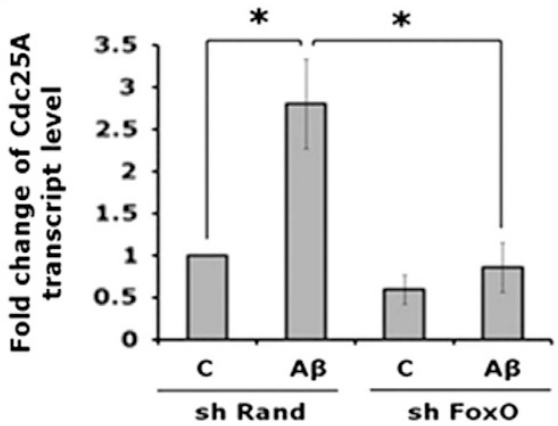

c

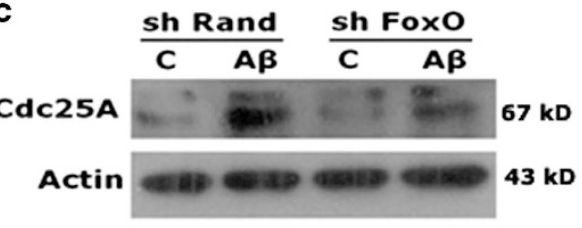

Figure 6. Downregulation of FoxO by shRNA blocks upregulation of Cdc25A in response to A $\beta$ treatment. (a) Upper panel: PC12 cells were neuronally differentiated and treated for $16 \mathrm{~h}$ with $A \beta$ in the presence or absence of the AKT inhibitor, AKTi. Cells were lysed and total protein was analyzed by western blotting analysis for Cdc25A and actin (loading control). Lower panel: graphical representation of the Cdc25A protein levels as quantified by densitometry. Data are represented as mean \pm S.E.M. of three independent experiments. Asterisks denote statistically significant differences between the indicated groups. ${ }^{*} P<0.05$. (b) PC12 cells were transfected with shRand or shFoxO and then differentiated in the presence of NGF for 5 days and then treated with A $\beta$ for 4 h. Total RNA was isolated from harvested cells and analyzed by qRT-PCR for Cdc25A transcript levels. GAPDH was used as a loading control. Data are represented as mean \pm S.D. of two independent experiments, ${ }^{*} P<0.05$. (c) PC12 cells were transfected with shRand or shFoxO, differentiated in the presence of NGF for 5 days and then treated overnight with $A \beta$. Cells were lysed and total protein was analyzed by western blotting for expression of Cdc25A and actin (loading control). A representative image from one of two experiments with similar results is shown.

Figure 5. Silencing of $\mathrm{Cdc} 25 \mathrm{~A}$ by an shRNA successfully blocks phosphorylation of Rb protein in response to NGF deprivation or $A \beta$ in neuronal PC12 cells. (a) Neuronal PC12 cells were transfected with the indicated constructs, maintained for $48 \mathrm{~h}$ and then subjected to NGF deprivation for $20 \mathrm{~h}$. Following NGF deprivation, cells were immunostained with antibody against phospho-Rb. Representative images from one of two different experiments with similar results are shown. Scale bar: $10 \mu \mathrm{m}$. (b) The percentage of transfected cells with high (more or equal than the neighboring non-transfected cells) or low (less than the neighboring non-transfected cells) phospho-Rb immunoreactivity levels in the presence and absence of NGF are shown. Data are represented as mean \pm S.D. of two experiments in duplicate. Asterisks denote statistically significant differences between indicated classes, ${ }^{*} P<0.01$. (c) Neuronally differentiated PC12 cells were transfected with the indicated constructs. Forty-eight hours post transfection cells were exposed overnight to $A \beta$ and immunostained for phospho-Rb. Representative images from one of three different experiments with similar results are shown. Scale bar: $10 \mu \mathrm{m}$. (d) The percentage of transfected cells with high (more or equal than the neighboring non-transfected cells) or low (less than the neighboring non-transfected cells) phospho-Rb immunoreactivity levels in control and $A \beta$-treated cells are shown. Data are represented as mean $\pm S$.D. of two experiments in duplicate. Asterisks denote statistically significant differences between indicated classes, ${ }^{*} P<0.01$. (e) Neuronally differentiated PC12 cells were deprived of NGF for $48 \mathrm{~h}$ in the presence and absence of 1 and $2 \mu \mathrm{m}$ of NSC95397. Total protein was subjected to western blot analysis using phospho-Rb antibody that specifically detects the Serine-780 phosphorylated form of the protein, which is phosphorylated by Cdk4. GAPDH was used as a loading control. (f) Neuronally differentiated PC12 cells were treated with anti-NGF in the presence and absence of $1 \mu \mathrm{m}$ of NSC95397 for $40 \mathrm{~h}$. Total protein was subjected to western blot analysis using specific cleaved Caspase-3 antibody. ERK1 was used as a loading control. A representative immunoblot of four independent experiments with similar results is shown. (g) Graphical representation of the cleaved caspase-3 protein levels as quantified by densitometry. Data are represented as mean \pm S.E.M. of four independent experiments, ${ }^{*} P<0.05$. 

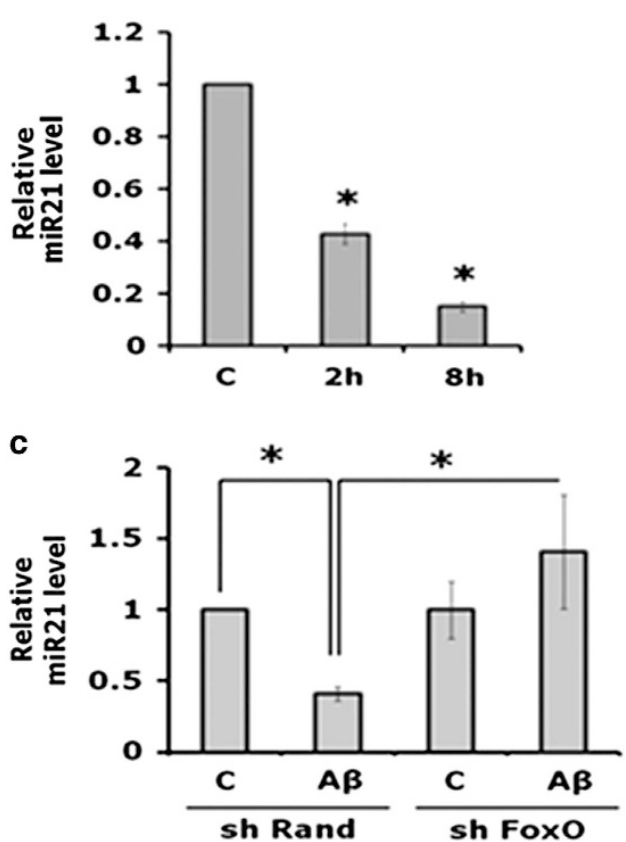

e

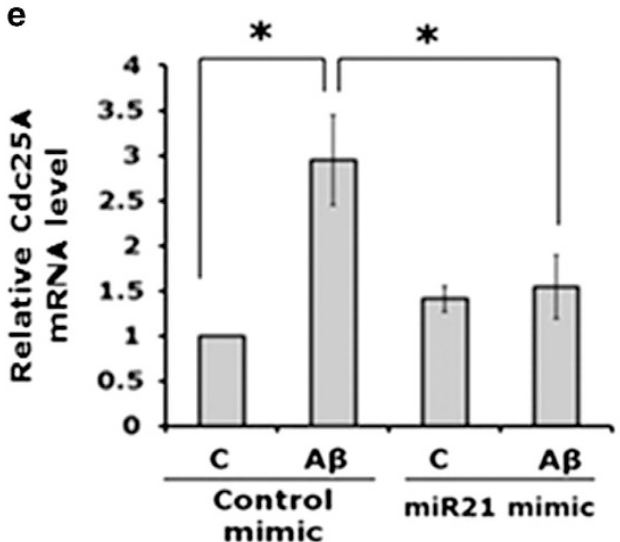

b

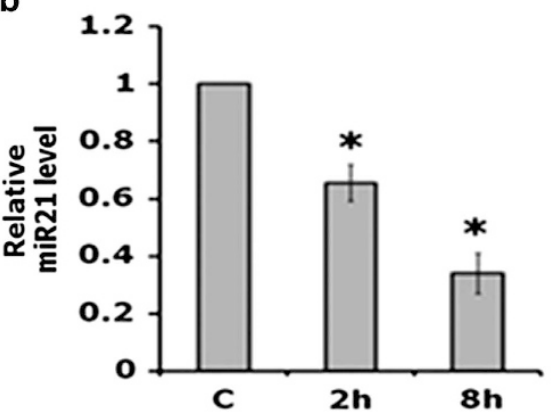

d

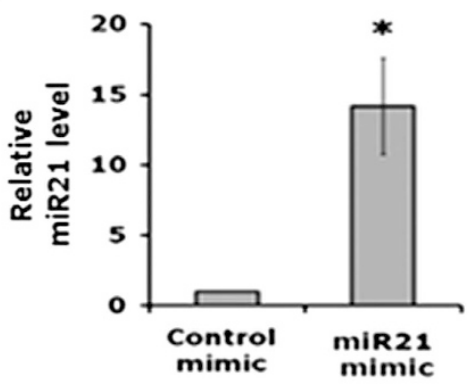

f
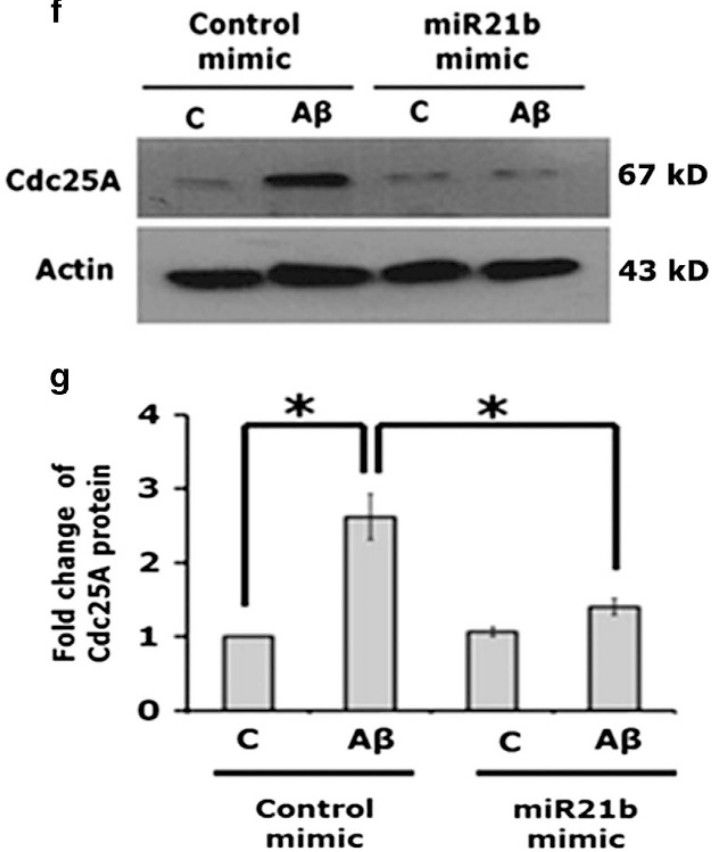

Figure 7. FoxO upregulates Cdc25A by suppressing miR-21 expression following $A \beta$ treatment. (a) Cultured cortical neurons (7 DIV) were treated with $A \beta$ for the indicated times. Total RNA was isolated and analyzed by qRT-PCR using the Taqman assay to quantify the relative miR-21 levels. Data are represented as mean \pm S.D. of two independent experiments, ${ }^{*} P<0.05$. (b) Cultured hippocampal neurons (21 DIV) were treated with A $\beta$ for the indicated times. Total RNA was isolated and analyzed by qRT-PCR using the Taqman assay to quantify the relative miR-21 levels. Data are represented as mean \pm S.D. of two independent experiments, $* P<0.05$. (c) PC12 cells were transfected with shRand or shFoxO and then differentiated in the presence of NGF for 5 days. Cultures were treated with $A \beta$ for $4 \mathrm{~h}$ and relative levels of miR-21 were determined by real-time PCR using the Taqman assay. Data are represented as mean \pm S.D. of two independent experiments, $* P<0.05$. (d) PC12 cells were transfected with control mimic or miR-21 mimic and differentiated in the presence of NGF for 5 days. Total RNA was isolated and analyzed by qRT-PCR using the Taqman assay for relative levels of miR-21 signal. (e) Neuronal PC12 cells (transfected with control or miR-21 mimic) were treated for $4 \mathrm{~h}$ with $\mathrm{A} \beta$. Total RNA was isolated and analyzed by qRT-PCR for relative Cdc25A levels. Data are represented as mean \pm S.D. of two independent experiments, ${ }^{*} P<0.05$. (f) Total lysates from cells treated with $A \beta$ for $16 \mathrm{~h}$ were analyzed by western blotting for Cdc25A and actin protein levels. Representative images of one of two experiments with similar results are shown here. (g) Graphical representation of the Cdc25A protein levels as quantified by densitometry of western blots in neuronal PC12 cells transfected with control or miR-21 mimic maintained in the presence or absence of A $\beta$. Data are represented as mean \pm S.D. of two independent experiments, ${ }^{*} P<0.05$. 


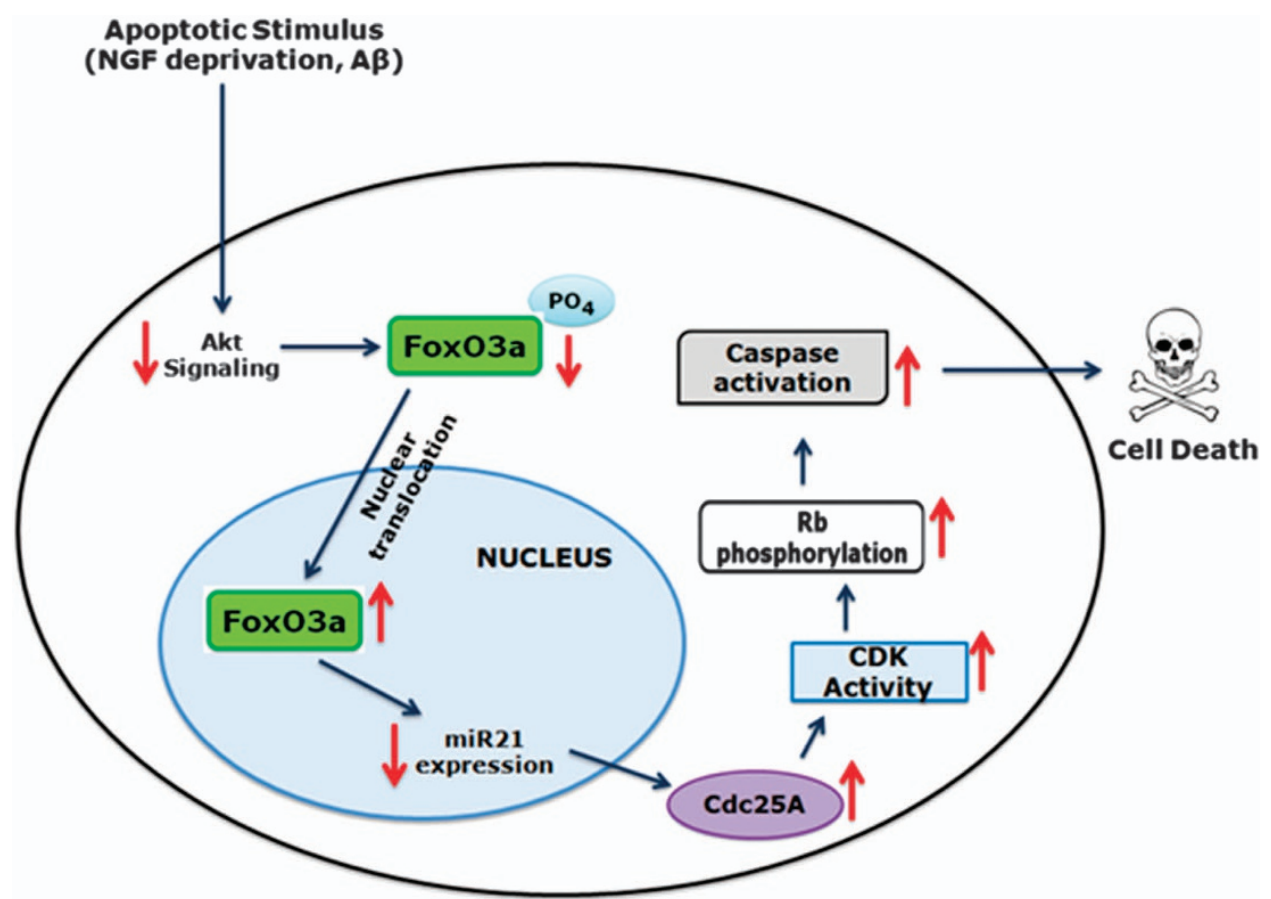

Figure 8. Schematic representation of the mechanism and consequences of Cdc25A induction in response to NGF deprivation or $A \beta$ treatment.

cultured in serum-free medium (DMEM/F12 (1:1)) supplemented with $6 \mathrm{mg} / \mathrm{ml}$ D-glucose, $100 \mu \mathrm{g} / \mathrm{ml}$ transferrin, $25 \mu \mathrm{g} / \mathrm{ml}$ insulin, $20 \mathrm{nM}$ progesterone, $60 \mu \mathrm{M}$ putrescine, $30 \mathrm{nM}$ selenium on poly-D-lysine coated plates. Cultures were used for experimentation 7 days after plating. Primary rat sympathetic culture was prepared as described earlier from superior cervical ganglia of neonatal rat pups. ${ }^{46}$ NGF deprivation was performed as described previously. ${ }^{47}$ In brief, the fully differentiated PC12 cells or sympathetic neurons were washed with NGF-free medium and anti-NGF antibody $(1: 100 ; 5 \mu \mathrm{g} / \mathrm{ml})$ was added. Control cells were washed with serum-free medium and maintained in NGF containing medium. To study the effect of $\mathrm{Cdc} 25$ inhibitors on differentiated PC12 cells or sympathetic neurons, cultures were subjected to NGF deprivation overnight in the presence and absence of inhibitors. The cells were then processed for cell survival or western blotting.

\section{Preparation of amyloid}

$A \beta_{(1-42)}$ and $A \beta_{(42-1)}$ were prepared as described earlier. ${ }^{48}$ In brief, HPLCpurified $A \beta_{(1-42)}$ and $A \beta_{(42-1)}$ were purchased from American Peptide. Lyophilized $A \beta_{(1-42)}$ or $A \beta_{(42-1)}$ was reconstituted in $100 \% 1,1,1,3,3,3$ hexafluoro-2-propanol (HFIP) at $1 \mathrm{mM}$, HFIP was removed by evaporation in a Speed Vac (Hamburg, Germany), then the material was resuspended at $5 \mathrm{mM}$ in anhydrous DMSO. This stock was then stored in $-80^{\circ} \mathrm{C}$. For use, the stock was diluted with PBS to a final concentration of $400 \mu \mathrm{M}$ and SDS was added to a final concentration of $0.2 \%$. The resulting solution was incubated at $37^{\circ} \mathrm{C}$ for $18-24 \mathrm{~h}$ and then diluted with PBS to a final concentration of $100 \mu \mathrm{M}$ and incubated at $37^{\circ} \mathrm{C}$ for $18-24 \mathrm{~h}$ before use.

\section{Assessment of cell survival}

The intact nuclear counting assay was performed as described earlier ${ }^{23}$ by using a detergent containing buffer that dissolves the cell contents, but leaves the nuclei intact. The intact nuclei were then counted using a hemocytometer. The number of live cells was expressed as the percentage of the total cell population.

\section{RNA isolation and PCR}

Total RNA was extracted using TRI reagent (Sigma) as described earlier. ${ }^{49}$ CDNA was prepared using the CDNA synthesis kit from Applied Biosystems (Waltham, MA, USA) following the manufacturer's protocol. For each reaction $100 \mu \mathrm{g}$ of total RNA was used. The CDNA synthesis was done using an oligo dT primer. The cDNA were used for semiquantitative and quantitative PCR using a BioRad (Hercules, CA, USA) and ABI step one plus machines, respectively, using specific primers. Primer sequences for Cdc25A were $5^{\prime}$-CAGCTTCCACACCAGTCTCT- $3^{\prime}$ and $5^{\prime}$-TTGACTGCCGATACC CATAT- $3^{\prime}$. The primers for $a$-tubulin were $5^{\prime}$-ATGAGGCCATCTATGACATC- $3^{\prime}$ and $5^{\prime}$-TCCACAAACTGGATGGTAC-3'. For semiquantitative PCR, products were analyzed on a $1.5 \%$ agarose gel and visualized by staining with ethidium bromide. Quantitative PCR (qRT-PCR) was performed using $A B I$ SYBR green master mix and ABI Step one plus machine following the manufacturer's protocol. For miRNA quantification, the RNA was isolated as described above and analyzed for microRNA levels using Taqman assay. The miRNA probes were purchased from Ambion (Life technologies).

\section{Western blotting}

The cells were pelleted and lysed in lysis buffer (10 mM Tris (pH 7.4), $150 \mathrm{mM} \mathrm{NaCl}$, 1\% Triton-X 100, 1 mM EDTA, 1 mM EGTA, $0.2 \mathrm{mM}$ activated orthovanadate) on ice for $20 \mathrm{~min}$. The lysates were centrifuged at $12000 \mathrm{r}$. p.m. for $10 \mathrm{~min}$. The supernatant was collected and used for western blotting analysis. Fifty micrograms of the proteins were resolved by SDSPAGE. After electrophoresis the proteins were transferred from the gel to PVDF (Hybond: GE Healthcare) membranes. The membranes were blocked with $5 \%$ non-fat dry milk (NFDM) (Biorad) in $1 \times$ TBST for $1 \mathrm{~h}$ at room temperature on a shaker. Then primary antibody was added and incubated overnight at $4{ }^{\circ} \mathrm{C}$ (5\% BSA in TBST was used as primary antibody diluent) on a rotating shaker. The membranes were washed three times for $5 \mathrm{~min}$ with TBST and the HRP-conjugated secondary antibody was added to the appropriate dilution and the membranes were incubated for $1 \mathrm{~h}$ on a shaker. The membranes were washed with TBST three times for $5 \mathrm{~min}$ and chemiluminescence assays were carried out using the Milipore classic luminol reagent according to the manufacturer's protocol. Signals were detected on X-ray films (Kodak, Windsor, CO, USA).

\section{Immunocytochemistry}

Immunocytochemical staining of cultured cells was carried out following previously described procedures. ${ }^{18,50}$ Briefly, neuronal cells were grown on glass coverslips, fixed with 4\% PFA, blocked with $3 \%$ goat serum in PBST for $1-2 \mathrm{~h}$ and then incubated overnight with primary antibody in blocking solution. After washing, the coverslips were incubated with secondary antibody for $1 \mathrm{~h}$ and then incubated with Hoechst dye for nuclear staining and imaged under fluorescence microscopy (Leica, Wetzlar, Germany) with a digital spot camera. 


\section{Phosphatase assay}

The $\operatorname{Cdc25A}$ phosphatase assay was performed using the $p$-nitrophenyl phosphate liquid substrate system (Sigma Aldrich, St Louis, MO, USA) according to the manufacturer's protocol. Briefly, the protein lysates were incubated with anti-Cdc25A antibody for overnight at $4{ }^{\circ} \mathrm{C}$ under shaking. The following day $25 \mu \mathrm{l}$ of protein A agarose was added and incubated for $2 \mathrm{~h}$. Then the agarose-conjugated $\mathrm{Cdc} 25 \mathrm{~A}$ were pelleted by centrifugation. The immunoprecipitated Cdc25A was incubated with $200 \mu \mathrm{l}$ of p-nitrophenyl phosphate liquid substrate for $30 \mathrm{~min}$ at room temperature in the dark. The absorbance of the solution was then read at $405 \mathrm{~nm}$ in an ELISA reader.

\section{Preparation of shRNA}

shRNAs were prepared in the pSIREN vector by using the BD Biosciences knockout RNAi system, according to the manufacturer's instructions on the basis of the following sequence $5^{\prime}$-gccattctgattctctaga- $3^{\prime}$.

\section{Transfection and gene silencing}

DNA was prepared with the Plasmid Maxi kit (Qiagen, Waltham, MA, USA). For the survival assay, neuronal cells were transfected with $0.5 \mu \mathrm{g}$ of the specific plasmid using Lipofectamine 2000 following the manufacturer's protocol. Six hour later, medium containing Lipofectamine 2000 and DNA was replaced with fresh complete medium. Experimental assays were performed $48 \mathrm{~h}$ post transfection. The numbers of surviving-transfected (green) cells per well were assessed just after treatment and at different time intervals as indicated.

\section{Survival assay}

Primary cortical neurons (5 DIV) and sympathetic neurons (5 DIV) were transfected with the indicated shRNA constructs. After $48 \mathrm{~h}$ of transfection, the neurons were exposed to $A \beta_{(1-42)}$ or anti-NGF, respectively. The numbers of transfected neurons (green) were counted immediately $(0 \mathrm{~h})$ and after 24 and $48 \mathrm{~h}$ of treatment. Neuronal PC12 cells were cultured in 24-well plates. After 3 days, cells were transfected with the indicated shRNAs using Lipofectamine 2000. Forty-eight hours post transfection, cells were washed with NGF-free medium twice and anti-NGF antibody $(1: 100)$ was added. The numbers of surviving-transfected cells were counted under fluorescent microscopy.

\section{Oligomeric $A \beta$ infusion in animals}

Infusion of $A \beta_{(1-42)}$ was performed as described earlier. ${ }^{23}$ Male SpragueDawley rats $(300-380 \mathrm{~g})$ were anesthetized by injecting a mixture of xylazine-ketamine and placing them on a stereotaxic frame. Injection was carried out by using a 27-gauge Hamilton syringe. A volume of $5 \mu \mathrm{l}$ of $100 \mathrm{mM} \mathrm{A} \beta_{1-42}$ in PBS was infused in the right cerebral cortex at stereotaxic co-ordinates from bregma: AP: -4.1 , L: 2.5 , DV: $1.3 \mathrm{~mm}$, according to a previous report. ${ }^{51}$ An equal volume of $A \beta_{42-1}$ in PBS was injected in control animals. Animals were killed 21 days after injection. The brains were dissected out, following cardiac perfusion, and fixed in 4\% PFA for $24 \mathrm{~h}$. They were then incubated in a 30\% sucrose solution for another $24 \mathrm{~h}$ before proceeding with cryosectioning (Cryotome; Thermo).

\section{Immunohistochemistry of brain slices}

Twenty micrometer brain cryosections from A $\beta$-infused or PBS-infused rats and wild-type or transgenic mice were blocked with $5 \%$ goat serum in PBS containing $0.3 \%$ Triton-X 100 for $1 \mathrm{~h}$ at room temperature. Sections were incubated in primary antibody in a blocking solution overnight at $4{ }^{\circ} \mathrm{C}$, washed thrice with PBS and incubated with a fluorescence-tagged secondary antibody for $2 \mathrm{~h}$ at room temperature. Following three washes with PBS and Hoechst dye nuclear staining, the sections were mounted and observed under fluorescence and confocal microscopy (Leica).

\section{Statistics}

The experimental results are reported as mean \pm S.E.M/S.D. Student's $t$-test was performed as unpaired, two-tailed sets of arrays to evaluate the significance of differences between the means of experimental and control groups and the results are presented as $P$-values. One-way ANOVA was performed for data sets of more than two groups.

\section{ABBREVIATIONS}

$A \beta, \beta$-amyloid; $A D$, Alzheimer's disease; $C d c 25 A$, cell division cycle $25 \mathrm{~A}$; CDK4, Cyclin dependent kinase 4; FoxO, forkhead box, class O; miR21, micro RNA 21; NGF, nerve growth factor; PC12, pheochromocytoma cells; $\mathrm{Rb}$, retinoblastoma; RNAi, RNA interference; shRNA, small hairpin RNA

\section{ACKNOWLEDGEMENTS}

The work was supported in part by one of the 12th Five Year Plan Projects, miND (BSC0115) of CSIR, Government of India and by the Department of Science and Technology, Government of India, Project SR/SO/BB-27/2010 (G) (to SCB) and by grant 2R01NS033689 (to LAG) from the National Institutes of Health. We would like to thank Dr AB Patel (CSIR-CCMB) for providing tissues of transgenic animals of Alzheimer's model. We thank Ms. Janet A Peterson for technical assistance.

\section{COMPETING INTERESTS}

The authors declare no conflict of interest.

\section{REFERENCES}

1 Oppenheim RW. Cell death during development of the nervous system. Annu Rev Neurosci 1991; 14: 453-501.

2 Hardy J. Amyloid, the presenilins and Alzheimer's disease. Trends Neurosci 1997; 20: 154-159.

3 Huang Y, Mucke L. Alzheimer mechanisms and therapeutic strategies. Cell 2012; 148: 1204-1222.

4 Selkoe DJ. Alzheimer's disease: genes, proteins, and therapy. Physiol Rev 2001; 81: 741-766.

5 Tanzi RE, Bertram L. Twenty years of the Alzheimer's disease amyloid hypothesis: a genetic perspective. Cell 2005; 120: 545-555.

6 Walsh DM, Selkoe DJ. A beta oligomers - a decade of discovery. J Neurochem 2007; 101: 1172-1184.

7 Cattaneo A, Calissano P. Nerve growth factor and Alzheimer's disease: new facts for an old hypothesis. Mol Neurobiol 2012; 46: 588-604.

8 lulita MF, Cuello AC. Nerve growth factor metabolic dysfunction in Alzheimer's disease and Down syndrome. Trends Pharmacol Sci 2014; 35: 338-348.

9 Copani A, Guccione S, Giurato L, Caraci F, Calafiore M, Sortino MA et al. The cell cycle molecules behind neurodegeneration in Alzheimer's disease: perspectives for drug development. Curr Med Chem 2008; 15: 2420-2432.

10 Folch J, Junyent F, Verdaguer E, Auladell C, Pizarro JG, Beas-Zarate C et al. Role of cell cycle re-entry in neurons: a common apoptotic mechanism of neuronal cell death. Neurotox Res 2012; 22: 195-207.

11 Frade JM, Ovejero-Benito MC. Neuronal cell cycle: the neuron itself and its circumstances. Cell Cycle 2015; 14: 712-720.

12 Greene LA, Biswas SC, Liu DX. Cell cycle molecules and vertebrate neuron death: E2F at the hub. Cell Death Differ 2004; 11: 49-60.

13 Greene LA, Liu DX, Troy CM, Biswas SC. Cell cycle molecules define a pathway required for neuron death in development and disease. Biochim Biophys Acta 2007; 1772: 392-401.

14 Herrup K, Yang Y. Cell cycle regulation in the postmitotic neuron: oxymoron or new biology? Nat Rev Neurosci 2007; 8: 368-378.

15 Lee HG, Casadesus G, Zhu X, Castellani RJ, McShea A, Perry G et al. Cell cycle re-entry mediated neurodegeneration and its treatment role in the pathogenesis of Alzheimer's disease. Neurochem Int 2009; 54: 84-88.

16 Vincent I, Rosado M, Davies P. Mitotic mechanisms in Alzheimer's disease? J Cell Biol 1996; 132: 413-425.

17 Biswas SC, Liu DX, Greene LA. Bim is a direct target of a neuronal E2F-dependent apoptotic pathway. J Neurosci 2005; 25: 8349-8358.

18 Biswas SC, Shi Y, Sproul A, Greene LA. Pro-apoptotic Bim induction in response to nerve growth factor deprivation requires simultaneous activation of three different death signaling pathways. I Biol Chem 2007; 282: 29368-29374.

19 Aressy B, Ducommun B. Cell cycle control by the CDC25 phosphatases. Anticancer Agents Med Chem 2008; 8: 818-824.

20 Greene LA, Tischler AS. Establishment of a noradrenergic clonal line of rat adrenal pheochromocytoma cells which respond to nerve growth factor. Proc Natl Acad Sci 1976; 73: 2424-2428.

21 Xu Z, Maroney AC, Dobrzanski P, Kukekov NV, Greene LA. The MLK family mediates C-Jun $\mathrm{N}$-terminal kinase activation in neuronal apoptosis. Mol Cell Biol 2001; 21: $4713-4724$. 
22 Matrone C, Di Luzio A, Meli G, D'Aguanno S, Severini C, Ciotti MT et al. Activation of the amyloidogenic route by NGF deprivation induces apoptotic death in PC12 cells. J Alzheimers Dis 2008; 13: 81-96.

23 Sanphui P, Biswas SC. FoxO3a is activated and executes neuron death via Bim in response to beta-amyloid. Cell Death Dis 2013; 4: e625.

24 Amente S, Zhang J, Lavadera ML, Lania L, Avvedimento EV, Majello B. Myc and PI3K/AKT signaling cooperatively repress FOXO3a-dependent PUMA and GADD45a gene expression. Nucleic Acids Res 2011; 39: 9498-9507.

25 Weidinger C, Krause K, Mueller K, Klagge A, Fuhrer D. FOXO3 is inhibited by oncogenic PI3K/Akt signaling but can be reactivated by the NSAID sulindac sulfide. J Clin Endocrinol Metab 2011; 96: E1361-E1371.

26 Gilley J, Coffer PJ, Ham J. FOXO transcription factors directly activate bim gene expression and promote apoptosis in sympathetic neurons. J Cell Biol 2003; 162: 613-622.

27 Zareen N, Biswas SC, Greene LA. A feed-forward loop involving Trib3, Akt and FoxO mediates death of NGF-deprived neurons. Cell Death Differ 2013; 20: 1719-1730.

28 Wang K, Li PF. Foxo3a regulates apoptosis by negatively targeting miR-21. J Biol Chem 2010; 285: 16958-16966.

29 Wang P, Zou F, Zhang X, Li H, Dulak A, Tomko RJ Jr et al. microRNA-21 negatively regulates $\mathrm{Cdc} 25 \mathrm{~A}$ and cell cycle progression in colon cancer cells. Cancer Res 2009; 69: 8157-8165.

30 Becker EB, Bonni A. Cell cycle regulation of neuronal apoptosis in development and disease. Prog Neurobiol 2004; 72: 1-25.

31 Heintz N. Cell death and the cell cycle: a relationship between transformation and neurodegeneration? Trends Biochem Sci 1993; 18: 157-159.

32 Park DS, Morris EJ, Padmanabhan J, Shelanski ML, Geller HM, Greene LA. Cyclin-dependent kinases participate in death of neurons evoked by DNAdamaging agents. J Cell Biol 1998; 143: 457-467.

33 Liu DX, Nath N, Chellappan SP, Greene LA. Regulation of neuron survival and death by $\mathrm{p} 130$ and associated chromatin modifiers. Genes Dev 2005; 19: 719-732.

34 Zhang Y, Qu D, Morris EJ, O'Hare MJ, Callaghan SM, Slack RS et al. The Chk1/ Cdc25A pathway as activators of the cell cycle in neuronal death induced by camptothecin. J Neurosci 2006; 26: 8819-8828.

35 Bernardi R, Liebermann DA, Hoffman B. Cdc25A stability is controlled by the ubiquitin-proteasome pathway during cell cycle progression and terminal differentiation. Oncogene 2000; 19: 2447-2454.

36 Fernandez-Vidal A, Mazars A, Manenti S. CDC25A: a rebel within the CDC25 phosphatases family? Anticancer Agents Med Chem 2008; 8: 825-831.

37 Ding XL, Husseman J, Tomashevski A, Nochlin D, Jin LW, Vincent I. The cell cycle Cdc25A tyrosine phosphatase is activated in degenerating postmitotic neurons in Alzheimer's disease. Am J Pathol 2000; 157: 1983-1990.

38 Chang KH, Vincent F, Shah K. Deregulated Cdk5 triggers aberrant activation of cell cycle kinases and phosphatases inducing neuronal death. J Cell Sci 2012; 125: 5124-5137.

39 Kruman II, Wersto RP, Cardozo-Pelaez F, Smilenov L, Chan SL, Chrest FJ et al. Cell cycle activation linked to neuronal cell death initiated by DNA damage. Neuron 2004; 41: 549-561.
40 Lee HK, Kumar P, Fu Q, Rosen KM, Querfurth HW. The insulin/Akt signaling pathway is targeted by intracellular beta-amyloid. Mol Biol Cell 2009; 20: 1533-1544.

41 Brunet A, Bonni A, Zigmond MJ, Lin MZ, Juo P, Hu LS et al. Akt promotes cell survival by phosphorylating and inhibiting a Forkhead transcription factor. Cell 1999; 96: 857-868.

42 Kar S, Wang M, Yao W, Michejda CJ, Carr BI. PM-20, a novel inhibitor of Cdc25A induces extracellular signal-regulated kinase $1 / 2$ phosphorylation and inhibits hepatocellular carcinoma growth in vitro and in vivo. Mol Cancer Ther 2006; 5 1511-1519.

43 Masyuk TV, Radtke BN, Stroope AJ, Banales JM, Masyuk AI, Gradilone SA et al. Inhibition of Cdc25A suppresses hepato-renal cystogenesis in rodent models of polycystic kidney and liver disease. Gastroenterology 2012; 142: 622-633.

44 Naderi A, Liu J. Inhibition of androgen receptor and Cdc25A phosphatase as a combination targeted therapy in molecular apocrine breast cancer. Cancer Lett 2010; 298: 74-87.

45 Troy CM, Rabacchi SA, Friedman WJ, Frappier TF, Brown K, Shelanski ML. Caspase-2 mediates neuronal cell death induced by beta-amyloid. J Neurosci 2000; 20: 1386-1392.

46 Zareen N, Greene LA. Protocol for culturing sympathetic neurons from rat superior cervical ganglia (SCG). J Vis Exp 2009; 20: 988.

47 Biswas SC, Greene LA. Nerve growth factor (NGF) down-regulates the Bcl-2 homology $3(\mathrm{BH} 3)$ domain-only protein Bim and suppresses its proapoptotic activity by phosphorylation. J Biol Chem 2002; 277: 49511-49516.

48 Biswas SC, Zhang Y, lyirhiaro G, Willett RT, Rodriguez Gonzalez Y, Cregan SP et al. Sertad1 plays an essential role in developmental and pathological neuron death. J Neurosci 2010; 30: 3973-3982.

49 Akhter R, Sanphui P, Biswas SC. The essential role of p53-up-regulated modulator of apoptosis (Puma) and its regulation by FoxO3a transcription factor in betaamyloid-induced neuron death. J Biol Chem 2014; 289: 10812-10822.

50 Saha P, Biswas SC. Amyloid-beta induced astrocytosis and astrocyte death Implication of FoxO3a-Bim-caspase3 death signaling. Mol Cell Neurosci 2015; 68: 203-211.

51 Frautschy SA, Baird A, Cole GM. Effects of injected Alzheimer beta-amyloid cores in rat brain. Proc Natl Acad Sci 1991; 88: 8362-8366.

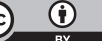

This work is licensed under a Creative Commons Attribution 4.0 International License. The images or other third party material in this article are included in the article's Creative Commons license, unless indicated otherwise in the credit line; if the material is not included under the Creative Commons license, users will need to obtain permission from the license holder to reproduce the material. To view a copy of this license, visit http://creativecommons.org/licenses/ by/4.0/

(c) The Author(s) 2016 